\title{
Assessment of the Relationship Between Nutrition and Obesity in Adolescence
}

\section{Adölesan Döneminde Beslenme ve Obezite Illişkisinin Değerlendirilmesi}

\author{
Aslıhan Şahiner ${ }^{1}$ (D), Burcu Yeşilkaya ${ }^{2}$ (D) \\ ${ }^{1}$ Istanbul Okan University, Institute of Health Sciences, Department of Nutrition and Dietetics, Istanbul, Turkey \\ ${ }^{2}$ Istanbul Okan University, Faculty of Health Sciences, Department of Nutrition and Dietetics, Istanbul, Turkey
}

ORCID ID: A.Ş. 0000-0003-4591-4765; B.Y. 0000-0001-9986-6119

Citation/Atıf: Sahiner A, Yesilkaya B. Assessment of the relationship between nutrition and obesity in adolescence. Çocuk Dergisi - Journal of Child 2021;21(2):119-127. https://doi.org/10.26650/jchild.2021.862283

\section{ABSTRACT}

Objective: Adolescent obesity is a widely important situation around the world. According to current studies, Turkey is the most obese country in Europe. For the improvement and protection of public health, adolescents should be guided for healthy eating habits. This studyaims todetermine the nutritional status of students in adolescenceand investigate their obesity status.

Material and Methods: The research is a descriptive study which has 204 students randomly selected from an Anatolian High School in Amasya. The data were collected through a questionnaire. The survey contains demographic information; eating habits and a food frequency form.

Results: According to the results, $59.3 \%$ female and $40.7 \%$ are male with the average age being $15.88 \pm 0.86$ years; the average weight $59.9 \pm 11.6 \mathrm{~kg}$; the average height $168.1 \pm 8.63 \mathrm{~cm}$; the average BMI $21.1 \pm 3.25 \mathrm{~kg} / \mathrm{m}^{2}$. In results, the percentiles of the Body Mass Index (BMI) by age and weight for age, females have more normal results $(p<0.05)$. The majority of participants had normal BMI values. The BMI values of the students who have an obese person in their family were higher $(p<0.05) .42 .6 \%$ of the students skipped meals while at home. The results of food frequency survey showed that protein, cholesterol, thiamine, riboflavin, sodium, calcium, magnesium, phosphorus and zinc were higher in males $(p<0.05)$. Conclusion: Adolescents need nutritional education on healthy eating, meal timing and snacking. It is recommended to provide nutrition education to students and families in institutions and to provide nutritionists for the monitoring of nutrition. It will affect adulthood and the next generations positively.

Keywords: Adolescent, Nutritional status, Obesity, Healthy life style öz

Amaç: Adölesanlarda obezite tüm dünyada oldukça önemli bir durumdur. Güncel araştırmalara göre Türkiye, Avrupa'nın en obez ülkesidir. Koruyucu sağıık politikaları önem kazanmıştır. Halk sağlığının iyileştirilmesi ve korunması için adölesanların sağılklı beslenme alıskanlıkları konusunda yönlendirilmesi gerekmektedir. Bu çalışmada adölesan dönemindeki öğrencilerin beslenme durumlarının belirlenmesi ve obezite durumlarının incelenmesi amaçlanmıştır.

Gereç ve Yöntem: Araştırma tanımlayıcı bir çalışmadır. Çalışma grubu Amasya'daki bir Anadolu Lisesi'nden rastgele seçilen 204 öğrenciden oluşmaktadır. Veriler, literatür taraması sonucunda araştırmacılar tarafından oluşturulan bir anket ile toplanmıştır. Anket demografik bilgileri, yeme alışkanlıkları ve bir besin tüketim sıklığı formunu içermektedir. Bulgular: Sonuçlara göre katılımcıların \%59,3'ü kız, \%40,7'si erkektir. Ortalama yaş $15,88 \pm 0,86^{\prime}$ dır; ortalama ağırlık $59,9 \pm 11,6 \mathrm{~kg}$ 'dı; ortalama boy $168.1 \pm 8.63 \mathrm{~cm}$; ortalama Beden Kitle Indeksi (BKi) $21.1 \pm 3.25 \mathrm{~kg} / \mathrm{m}^{2 \prime} \mathrm{dir}$. Sonuçlarda yaşa ve ağırlığa göre BKi persentilleri, kızlarda erkeklere göre daha normal bulunmuştur $(p<0.05)$. Katılımcıların çoğunluğunun normal BKi değerlerine sahip olduğu görüldü. Ailelerinde obez birey olan öğrencilerin BKi değerleri daha yüksek olarak saptandı $(p<0.05)$. Öğrencilerin $\% 42,6$ 'sı evdeyken öğün atladığını belirtti. Gıda sıklığı anketinin sonuçları; erkeklerde protein, kolesterol, tiamin, riboflavin, sodyum, kalsiyum, magnezyum, fosfor ve çinko kızlara göre daha yüksek bulundu ( $p<0.05)$.

Sonuç: Araştırma sonuçlarına göre adölesanların sağlıklı beslenme, öğün zamanlaması, atıştırma konularında beslenme eğitimine ihtiyaçları vardır. Kurumlarda öğrenci ve ailelere beslenme eğitimi verilmesi ve beslenme takibi için beslenme uzmanlarının sağlanması önerilmektedir. Bu destek, yetişkinlik dönemini ve ailesinin diğer nesillerini olumlu yönde etkileyeceği düşünülmektedir.

Anahtar Kelimeler: Adölesan, Beslenme durumu, Obezite, Sağlıkı yaşam tarzı

Corresponding Author/Sorumlu Yazar: Burcu Yeşilkay E-mail: burcuyavunc@hotmail.com

Submitted/Başvuru: 15.01.2021 • Revision Requested/Revizyon Talebi: 25.01.2021 • Accepted/Kabul: 07.05.2021 


\section{INTRODUCTION}

\section{Adolescent period and stages}

According to the the World Health Organization, the 10-19 age group is defined as adolescent. It is generally accepted as the transition period from childhood to adulthood and it is the period when reaching physical and psychological social maturity is completed. This process is the period in which one creates an identity, makes sense of one's self, and replans and adapts the behaviors from one's childhood. Those who do not have sufficient self-confidence have difficulty in acquiring skills that need to be acquired by entering into an anxious and anxious personality during this transition period (1). The characteristic of this period is rapid physical growth, sexual development, psychosocial maturation, and significant increases in organs, glands, bone, muscle, and fat mass (2). In its 2011 report, UNICEF divided adolescence period into early adolescence (10-14 years) and late adolescence (15-19 years). According to another classification, the psychosocial development process in adolescents there as three divisions: Early adolescence (10-13 years), middle adolescence (14-17 years), and late adolescence (17-21 years) (3).

\section{Nutrition in adolescents}

Nutrition is one of the other important factors affecting an adolescent. The amount of calories taken, healthy fats, and protein play an important role in growth and development (4). Especially in developing countries, there are many problems related to the diet of adolescents. Bad habits acquired from the very beginning of their lives may cause an inability to obtain the necessary vitamins and minerals for the body, obesity, heart disease, diabetes and many other chronic diseases and a poor quality life. Therefore, it is very important to detect this situation (5). Adolescence is the second period when the growth rate after infancy is the highest in terms of the magnitude of changes in the body. More energy is needed due to the excess of hormonal and physical changes (changes in fat, muscle, bone tissue) experienced during this period. $15 \%$ of adult height and $50 \%$ of weight are acquired during this period (6). The energy requirement for adolescents is calculated according to the growth spurt. Adolescents have growth spurts between different ages and their energy needs are higher than adults because they have a rapid growth process. There is a positive relationship between energy intake and growth. Especially, while the energy need increases around 16 years of age in boys, an average of 12 years is observed in girls, and this increase begins to decrease as the age increases (7). The average daily amount of energy recommended for adolescentsis 40 calories per kilogram for girls ages 15-18 (8). While girls between the ages of 11-18 should consume approximately 2200 calories per day in adolescence, boys between the ages of 11-18 are calculated to need to consume approximately 2500-2800 calories per day (9).

In a study, energy consumption of $28 \%$ of boys and $15 \%$ of girls was found to be higher than the recommended amount (10). Carbohydrates are the most important source of energy for adolescents. Carbohydrate-rich foods such as fruits, vegetables and whole grains are also an important source of fibre in the diet. It has been accepted that for a healthy development in the adolescent period, $45-65 \%$ of the total daily energy should come from carbohydrates, $10-20 \%$ from protein and $25-35 \%$ from fat (11). Daily carbohydrate consumption was found to be higher in $2 \%$ of boys and $5.4 \%$ of girls (8).

Adequate and balanced energy intake ensures the correct progress of growth and development in the adolescent period. Adequate protein intake and full coverage of essential amino acid needs are also very important in adolescence, and insufficient protein intake adversely affects growth and increases inflammation rate (12).

\section{Obesity during adolescence}

Obesity, one of the biggest health problems of today, is defined as an energy metabolism disorder that occurs with an excess calorie intake. According to World Health Organization (WHO) data, more than 300 million people have been diagnosed with obesity. The prevalence of obesity in the United States of America, $35.7 \%, 26.4 \%$ is indicated in the range of $10-30 \%$ in European countries and Turkey (13). According to the latest research conducted by the WHO (published on 10 October 2017), there were 11 million obese children between the ages of 5 and 19 in 1975, while in 2016, this rate doubled by approximately 10.124 million obese children. There were also 216 million overweight children (14).

In the HBSC (Health Behavior in School-aged Children) 20012002 research, It is stated that in Turkey, there is an obesity prevalence of $7 \%$ in girls and $14 \%$ in boys aged $11,7 \%$ of girls and $13 \%$ of boys aged and $5 \%$ of girls and $14 \%$ of boys aged 15 .

Childhood obesity rates were once on the rise in high-income countries and are now at a steady value, but unfortunately this value is very high. East Asia, the Middle East and North Africa are the regions with the highest increase in the number of obese children and adolescents in the world. The increase in childhood obesity rates has been rapid, especially in Asia (14). Many studies show that obesity continues in adulthood in individuals who were obese in childhood. It is reported that $30 \%$ of obese children are also are obese in adulthood (16).

\section{Factors affecting obesity}

Genetic characteristics, hormones and metabolic factors, dietary habits, lack of physical activity, alcohol and smoking, environmental characteristics such as socio-economic status, and psychological conditions affect the occurrence of obesity (15).

Genetic Factors; In many studies on obesity, it has been reported that energy metabolism, appetite state, fat metabolism, fat cell number and size are related to genes (16). The prevalence of obesity in the family is defined as a risk factor for childhood and adolescent obesity. Although the genes that cause obesity are not known exactly, it is known that the family plays a role in the obesity seen in adolescents both genetically and environmentally (16). Bad eating habits; The prevalence of obesity is increasing in direct proportion 
with the widespread consumption of easily available fast-food, increasing the portions, and the increase in the production of foods with high energy and carbohydrate content. In studies conducted to determine the eating behaviors of obese people, it is reported that these individuals are more prone to consume foods with high fat and energy content compared to individuals with normal weight (17). The frequency, amount and content of meals significantly affect the occurrence of obesity in adolescents. With the increase in meals consumed outside, consumption of fat and carbonated beverages among adolescents also increase. Since the energy level of fat is higher than other food groups and the thermogenesis created by the fat taken in the body is lower, it also increases obesity (18). Physical activity level; One of the causes of obesity is the amount of energy taken into the body is more than amount of energy used. It causes anenergy imbalance in the body. The amount of energy taken in adolescents is spent for basal metabolism, for growth and development, and for tissue regeneration. It has been observed that increased adipose tissue and obesity presence decrease the basal metabolic rate in body. In this case, increasing physical activity in order to ensure positive energy balance is one of the most important factors in preventing obesity (19). Long-term television and computer use, games that are mostly spent at home, and long sedentary working hours for exams are usually limits to physical activity. It causes anenergy imbalanceand increases the adipose tissue. It causes obesity in adolescents (16).

\section{MATERIAL AND METHODS}

This research is a cross-sectional descriptive study. The aim of the study was to determine the nutritional status of adolescents and to determine their obesity status. The study was carried out with the participation of a total of 204 students from an Anatolian high school in Amasya. The data were collected through a questionnaire created by the researchers as a result of a literature review. The survey contains demographic information; questions about determining eating habits; food frequency form. In the first part of the questionnaire, body weight $(\mathrm{kg})$, height $(\mathrm{m})$ and $\mathrm{BMI}\left(\mathrm{kg} / \mathrm{m}^{2}\right)$ are included among the anthropometric measurements. A household scale was used for weight measurement and a tape measure was used for height measurement. According to suggestions by the Society of Endocrinology and Metabolism of Turkey, the adolescent obesity research was investigated according to BMI percentiles (20). Students' height for their age, weight for their age and BMI percentile values for their age were calculated. The results of these calculations have been classified according to the references given below.

Height for age percentiles classified according to WHO; <5: Short, 5-95: Normal and >95: Tall (21). Weightforage reference data are not available beyond age 10 because this indicator does not distinguish between height and body mass in an age period where many children are experiencing the pubertal growth spurt and may appear as having excess weight (by weight-for-age) when in fact they are just tall. WHO (20). Weight for age percentile values from the percentile values,
TürkiyeBeslenme Rehberi (TUBER)-2015; <3: Weak, 3-15: Risk of Weakness, 15-85: Normal, 85-97: Overweight and > 97: Obese (22).From the percentile values, BMI percentile values according to age, TUBER values were taken, grouped and compared as <3: Weak, 3-15: Risk of Weakness, 15-85: Normal, 85-97: Overweight and >97: Obese (22).

\section{Ethical consent of the study}

In order to conduct the study, permission was obtained from the ethics committee of Istanbul Okan University with the meeting numbered 110 dated 12.06.2019 and number 3 . In addition, permission was obtained from Amasya Anatolian High School Directorate on 28.05.2019 at the place where the research was conducted. An information form was given to the students and a voluntary consent form was obtained. This work is in accordance with the principles of the Declaration of Helsinki.

\section{Statistical analysis of data}

The statistical analysis of the study was carried out with the SPSS 22.0 program. Frequency, percentage (\%), mean, standard deviation $( \pm)$, maximum and minimum values were used in descriptive statistical analyses. Pearson's chi-square test was used for comparisons of categorical variables. Whether the data showed normal distribution or not was examined with the Kolmogrov Smirnov test. Normal distribution was not observed in all of the data, and a Mann Whitney $U$ test was used for paired comparisons and Kruskal Wallis $\mathrm{H}$ test for triple comparisons. Post-hoc analysis was performed by pairwise comparison via Model Viewer. The analysis of the scale data was carried out by a Spearman correlation analysis after the determination that it did not show a normal distribution in order to determine the relationship. The findings of the data obtained in the study were interpreted within the scope of a $5 \%$ error margin and $95 \%$ confidence interval and the result was obtained (Significance value $=p<0.05$ ).

\section{RESULTS}

\section{Demographic and anthropometric outputs}

The sample of the study consisted of 204 students who are studying in a public high school. The gender distribution of the participants was $59.3 \%$ female and $40.7 \%$ male. The average age of the students were $15.88 \pm 0.86$ years. The average weight was $59.9 \pm 11.6 \mathrm{~kg}$; and the average height was $168.1 \pm 8.63 \mathrm{~cm}$; Their BMI is $21.1 \pm 3.25$ on average. The average number of children in their family was found to be $2.51 \pm 0.95$. When the anthropometric measurements of the students were compared according to their gender, significant differences were found in terms of height and weight. Accordingly, males' height and weight are higher than females'. However, when examined in terms of BMI, no significant difference was found between genders.

According to the BMI for age percentile values; $71.1 \%$ of them were in normal range; according to height for age percentile values, $94.1 \%$ of them were in the normal range and according to weight for age percentile values, $76.0 \%$ of them were in the normal range (Table 1$)$. 
Table 1: Distribution of students percentile values

\begin{tabular}{|c|c|c|}
\hline & $\mathbf{n}$ & $\%$ \\
\hline \multicolumn{3}{|l|}{ Weight for Age } \\
\hline Poor ( $\leq \% 3)$ & 4 & 2.0 \\
\hline Risk of poor (\%3-\%15) & 10 & 4.9 \\
\hline Normal (\%15-\%85) & 155 & 76.0 \\
\hline Overweight (\%85-\%97) & 29 & 14.2 \\
\hline Obese ( $\geq \% 97)$ & 6 & 2.9 \\
\hline \multicolumn{3}{|l|}{ BMI for age } \\
\hline Poor $(\leq \% 3)$ & 5 & 2.5 \\
\hline Risk of poor (\%3-\%15) & 19 & 9.3 \\
\hline Normal (\%15-\%85) & 145 & 71.1 \\
\hline Overweight (\%85-\%97) & 26 & 12.7 \\
\hline Obese ( $\geq \% 97)$ & 9 & 4.4 \\
\hline \multicolumn{3}{|l|}{ Height for Age } \\
\hline Short $(\leq \% 5)$ & 2 & 1.0 \\
\hline Normal (\%5-\%95) & 192 & 94.1 \\
\hline Tall ( $\geq \% 95)$ & 10 & 4.9 \\
\hline Total & 204 & 100.0 \\
\hline
\end{tabular}

BMI: Body Mass Index

When the distribution of gender and percentile values was examined, a significant difference was found $(p=0.033<0.05)$. Accordingly, it was determined that females have more normal range and a lower weight than males. When the gender was compared in terms of weight for age percentiles, a significant difference was found $(p=0.009<0.05)$. Accordingly, females have more normal BMI values than males. When the genders compared to height for age percentile, it was found that there was no significant difference ( $p>0.05$ ), (Table 2 ).

It was asked that if there is any overweight/obese individual in their families or not; $31.4 \%$ answered as "yes". A significant difference was found when the BMI values compared to the presence of an overweight/obese person in the families of the students. Accordingly, the BMI values of the students who have an overweight/obese family member have higher BMI values than others who has not.

\section{Nutritional status outcomes}

The daily energy, macronutrient and micronutrient consumption amounts were calculated from the food frequency form. The data was compared to the gender and it was found that there is a significant difference between; protein and cholesterol, while no significant difference was found between other macronutrient consumption and gender. It has been reported that males consume more protein and cholesterol than females (Table 3). There was also a significant difference between thiamine, riboflavin, sodium, calcium, magnesium, phosphorus and zinc, while no significant difference was found between other micronutrient consumption and gender. It is reported that, males consume more micronutrients than females in terms of thiamine, riboflavin, sodium, calcium, magnesium, phosphorus and zinc (Table 4).

Table 2: Distribution of weight for age, BMI for age and height for age percentile values according to the gender

\begin{tabular}{|c|c|c|c|c|c|c|c|c|}
\hline & & \multicolumn{2}{|c|}{ Female } & \multicolumn{2}{|c|}{ Erkek } & \multicolumn{2}{|c|}{ Total } & \multirow{2}{*}{ p* } \\
\hline & & $\mathrm{n}$ & $\%$ & $\mathrm{n}$ & $\%$ & $\mathrm{n}$ & $\%$ & \\
\hline \multirow[t]{6}{*}{ Weight for Age } & Poor & 1 & 0.8 & 3 & 3.6 & 4 & 2.0 & \\
\hline & Risk of poor & 9 & 7.4 & 1 & 1.2 & 10 & 4.9 & \\
\hline & Normal & 97 & 80.2 & 58 & 69.9 & 155 & 76.0 & $0.009 *$ \\
\hline & Overweight & 13 & 10.7 & 16 & 19.3 & 29 & 14.2 & \\
\hline & Obese & 1 & 0.8 & 5 & 6.0 & 6 & 2.9 & \\
\hline & Total & 121 & 100.0 & 83 & 100.0 & 204 & 100.0 & \\
\hline \multirow[t]{6}{*}{ BMI for age } & Poor & 2 & 1.7 & 3 & 3.6 & 5 & 2.5 & $0.033^{*}$ \\
\hline & Risk of poor & 11 & 9.1 & 8 & 9.6 & 19 & 9.3 & \\
\hline & Normal & 95 & 78.5 & 50 & 60.2 & 145 & 71.1 & \\
\hline & Overweight & 9 & 7.4 & 17 & 20.5 & 26 & 12.7 & \\
\hline & Obese & 4 & 3.3 & 5 & 6.0 & 9 & 4.4 & \\
\hline & Total & 121 & 100.0 & 83 & 100.0 & 204 & 100.0 & \\
\hline \multirow[t]{4}{*}{ Height for Age } & Short & 1 & 0.8 & 1 & 1.2 & 2 & 1.0 & 0.424 \\
\hline & Normal & 116 & 95.9 & 76 & 91.6 & 192 & 94.1 & \\
\hline & Tall & 4 & 3.3 & 6 & 7.2 & 10 & 4.9 & \\
\hline & Total & 121 & 100.0 & 83 & 100.0 & 204 & 100.0 & \\
\hline
\end{tabular}

*Chi-Square Analysis, p<0.05, BMI: Body Mass Index 
Table 3: Energy macro-nutrients and pulp intake average of the students in daily diet according to gender

\begin{tabular}{|c|c|c|c|c|c|c|c|c|}
\hline & & $\mathrm{n}$ & $\bar{x} \pm s . s$ & Min. & Max. & RDA & RDA \% & $\mathrm{P}^{*}$ \\
\hline \multirow[t]{3}{*}{ Energy (kcal) } & Female< & 121 & $1405.07 \pm 540.08$ & 447.68 & 4073.47 & 2260 & 62.17 & 0.061 \\
\hline & Male & 83 & $1556.72 \pm 576.87$ & 640.08 & 3361.05 & 2860 & 54.43 & \\
\hline & Total & 204 & $1466.77 \pm 558.95$ & 447.68 & 4073.47 & - & - & \\
\hline \multirow[t]{3}{*}{ Protein (g) } & Female & 121 & $46.62 \pm 22.57$ & 16.91 & 183.54 & 45 & 103.60 & $0.008^{*}$ \\
\hline & Male & 83 & $52.91 \pm 19.73$ & 24.71 & 123.65 & 65 & 81.39 & \\
\hline & Total & 204 & $49.18 \pm 21.64$ & 16.91 & 183.54 & - & - & \\
\hline \multirow[t]{3}{*}{ Protein (\%) } & Female & 121 & $23.79 \pm 1.41$ & 12.00 & 24.00 & $9-20$ & - & 0.523 \\
\hline & Male & 83 & $23.88 \pm 1.1$ & 14.00 & 24.00 & $8-20$ & - & \\
\hline & Total & 204 & $23.82 \pm 1.29$ & 12.00 & 24.00 & - & - & \\
\hline \multirow[t]{3}{*}{ Fat (g) } & Female & 121 & $64.4 \pm 25.63$ & 11.88 & 181.84 & - & - & 0.103 \\
\hline & Male & 83 & $70.31 \pm 25.14$ & 29.45 & 150.36 & - & - & \\
\hline & Total & 204 & $66.8 \pm 25.53$ & 11.88 & 181.84 & - & - & \\
\hline \multirow[t]{3}{*}{ Fat (\%) } & Female & 121 & $40.57 \pm 6$ & 22.00 & 55.00 & $20-35$ & - & 0.757 \\
\hline & Male & 83 & $40.31 \pm 4.37$ & 31.00 & 51.00 & $20-35$ & - & \\
\hline & Total & 204 & $40.47 \pm 5.39$ & 22.00 & 55.00 & - & - & \\
\hline \multirow[t]{3}{*}{ Carbohydrates (g) } & Female & 121 & $158.03 \pm 63.18$ & 39.48 & 418.21 & 130 & 121.56 & 0.092 \\
\hline & Male & 83 & $176.15 \pm 72.9$ & 64.92 & 407.21 & 130 & 135.49 & \\
\hline & Total & 204 & $165.4 \pm 67.72$ & 39.48 & 418.21 & - & - & \\
\hline \multirow[t]{3}{*}{ Carbohydrates (\%) } & Female & 121 & $45.99 \pm 6.62$ & 31.00 & 66.00 & $45-60$ & - & 0.751 \\
\hline & Male & 83 & $45.67 \pm 5.06$ & 33.00 & 56.00 & $45-60$ & - & \\
\hline & Total & 204 & $45.86 \pm 6.02$ & 31.00 & 66.00 & - & - & \\
\hline \multirow{3}{*}{$\begin{array}{l}\text { Polyunsaturated } \\
\text { fatty acids (g) }\end{array}$} & Female & 121 & $13 \pm 5.33$ & 2.91 & 36.03 & - & - & 0.380 \\
\hline & Male & 83 & $13.92 \pm 5.86$ & 4.68 & 31.29 & - & - & \\
\hline & Total & 204 & $14.49 \pm 5.86$ & 2.91 & 36.03 & - & - & \\
\hline \multirow[t]{3}{*}{ Fiber (g) } & Female & 121 & $14.07 \pm 5.58$ & 4.67 & 34.50 & 26 & 54.11 & 0.239 \\
\hline & Male & 83 & $15.1 \pm 6.23$ & 5.54 & 34.50 & 29 & 5.06 & \\
\hline & Total & 204 & $13.38 \pm 5.55$ & 4.67 & 34.50 & - & - & \\
\hline \multirow[t]{3}{*}{ Cholesterol (mg) } & Female & 121 & $218.88 \pm 117.91$ & 58.07 & 833.72 & - & - & $0.001^{*}$ \\
\hline & Male & 83 & $271.51 \pm 120.46$ & 90.17 & 565.32 & - & - & \\
\hline & Total & 204 & $240.29 \pm 121.46$ & 58.07 & 833.72 & - & - & \\
\hline
\end{tabular}

*Mann-Whitney U Analysis, p<0.05. BMI: Body Mass Index

When the relationship between the height, weight and $\mathrm{BMI}$ values of the food consumption; there is a significantly positive relationship between cholesterol and height (14.3\%) and calcium and height (15.2\%). It was also found that there is a significantly negative relationship between carbohydrates and weight (15.9\%), and a significantly negative relationship between carbohydrate percentage and BMI (17.3\%), while there is a significantly positive relationship between cholesterol and weight (14.9\%). There was no significant relationship between other food items and height, weight and BMI values. The water consumption per day was also examined. $36.8 \%$ of them were consuming $600 \mathrm{ml}-1000 \mathrm{ml}$ and $36.3 \%$ of them were consuming $1001-1800 \mathrm{ml}$ water.

\section{Nutrition behavior outcomes}

The number of meals consumed was $2.65 \pm 0.54$ meals per day and $1.61 \pm 1.22$ snacks per day. When the relationship between "skipping meals" and "being at home" was examined, it was found that $56.9 \%$ of them skip meals while at home, and $48.0 \%$ of them skip meals while at school. When asked about the "frequency of fast-food consumption", the majority (32.8\%) stated that they consume 2-4 per week; $31.4 \%$ of them stated that they consume once a week. There was no statistically significant difference between skipping meals and their regular breakfast habits compared with their BMI values $(p>0.05)$. When the relationship between the number of meals consumed daily and anthropometric measurements is examined; a weak negative correlation was found between the number of main 
Table 4: Average vitamin and mineral intake of the students in daily diet according to gender

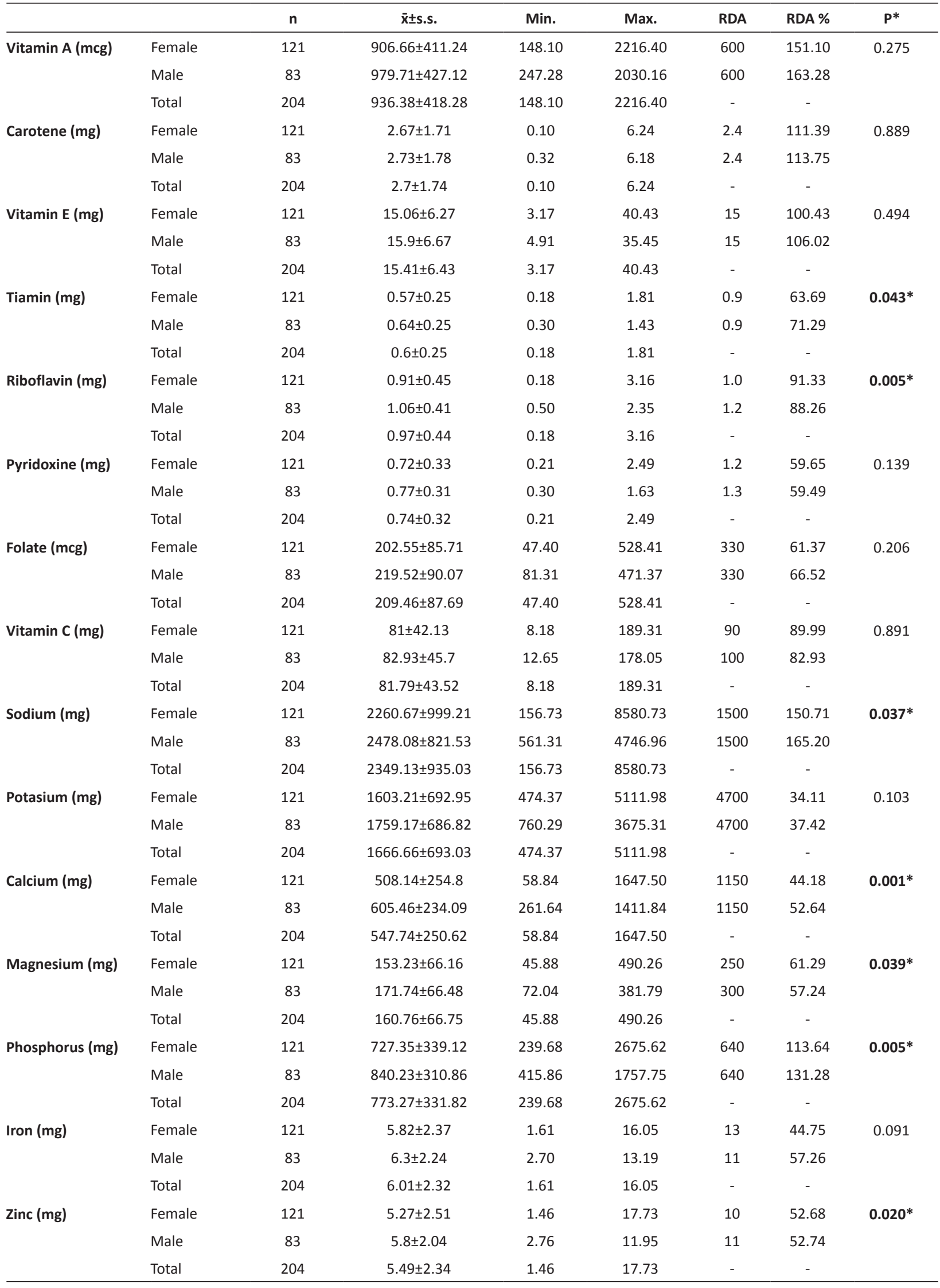

*Mann-Whitney U Analysis, $\mathrm{p}<0.05$ 
Table 5: The relationship between height, weight and BMI values of students with food consumption

\begin{tabular}{|c|c|c|c|c|c|c|}
\hline & \multicolumn{2}{|c|}{ Height (cm) } & \multicolumn{2}{|c|}{ Weight (kg) } & \multicolumn{2}{|c|}{ BMI } \\
\hline & $r^{*}$ & p & $\mathbf{r}$ & $\mathbf{p}$ & $\mathbf{r}$ & $\mathbf{p}$ \\
\hline Energy (kkal) & 0.086 & 0.220 & 0.012 & 0.866 & -0.046 & 0.512 \\
\hline Protein (g) & 0.100 & 0.155 & 0.094 & 0.183 & 0.044 & 0.529 \\
\hline Protein (\%) & 0.025 & 0.719 & 0.025 & 0.719 & 0.049 & 0.489 \\
\hline Fat (g) & 0.105 & 0.136 & 0.063 & 0.374 & 0.014 & 0.846 \\
\hline Fat (\%) & 0.037 & 0.599 & 0.106 & 0.132 & 0.122 & 0.081 \\
\hline Carbohydrate (g) & 0.064 & 0.362 & -0.040 & 0.574 & -0.102 & 0.147 \\
\hline Carbohydrate (\%) & -0.050 & 0.477 & $-0.159 *$ & 0.023 & $-0.173 *$ & 0.014 \\
\hline Polyunsaturated fatty acids (g) & 0.073 & 0.302 & 0.032 & 0.646 & -0.012 & 0.870 \\
\hline Fiber (g) & 0.072 & 0.306 & 0.048 & 0.496 & 0.018 & 0.800 \\
\hline Cholesterol (mg) & $0.143^{*}$ & 0.041 & $0.149 *$ & 0.034 & 0.087 & 0.215 \\
\hline Vitamin A (mcg) & 0.135 & 0.054 & $0.138^{*}$ & 0.049 & 0.095 & 0.176 \\
\hline Carotene (mg) & 0.077 & 0.276 & 0.106 & 0.130 & 0.094 & 0.183 \\
\hline Vitamin E (mg) & 0.063 & 0.373 & 0.085 & 0.228 & 0.078 & 0.270 \\
\hline Tiamin (mg) & 0.102 & 0.148 & 0.077 & 0.276 & 0.027 & 0.701 \\
\hline Riboflavin (mg) & 0.125 & 0.074 & 0.109 & 0.121 & 0.054 & 0.439 \\
\hline Pyridoxine (mg) & 0.100 & 0.155 & 0.114 & 0.105 & 0.080 & 0.254 \\
\hline Folate (mcg) & 0.073 & 0.302 & 0.081 & 0.247 & 0.056 & 0.426 \\
\hline Vitamin C (mg) & 0.075 & 0.284 & 0.097 & 0.170 & 0.086 & 0.220 \\
\hline Sodium(mg) & 0.116 & 0.100 & 0.071 & 0.313 & 0.017 & 0.810 \\
\hline Potasium (mg) & 0.096 & 0.173 & 0.108 & 0.125 & 0.076 & 0.281 \\
\hline Calcium (mg) & $0.152 *$ & 0.029 & 0.124 & 0.076 & 0.067 & 0.338 \\
\hline Magnesium (mg) & 0.101 & 0.151 & 0.067 & 0.341 & 0.017 & 0.813 \\
\hline Phosphorus (mg) & 0.114 & 0.106 & 0.104 & 0.139 & 0.055 & 0.436 \\
\hline Iron (mg) & 0.068 & 0.332 & 0.013 & 0.857 & -0.039 & 0.577 \\
\hline Zinc (mg) & 0.102 & 0.147 & 0.079 & 0.263 & 0.025 & 0.720 \\
\hline
\end{tabular}

* Spearman Correlation Analysis, p<0.05.BMI: Body Mass Index

meals and BMI values (15.7\%). Considering the situation of students "availability of healthy food at school canteen", $44.1 \%$ of them mentioned that healthy food is available at the school canteen sometimes. It was also determined that $41.2 \%$ of the students were shopping from the canteen $2-4 /$ week and most of them (87.3\%) shopped for lunch. The students reported that they consume mostly packaged foods $(43.1 \%)$ as a food; and water $(44.3 \%)$ and dairy products $(20.6 \%)$ as drink.

Food frequency data and BMI values were examined and there were no significant difference between BMI values and frequency of fast food consumption and the frequency of shopping from the school canteen. A significant difference was found between the amount of water consumption and BMI values. When the significance is examined, those who consume 6-9 glasses (1200-1800ml) of water have a higher BMI than those who consume $3-5$ glasses $(600-1000 \mathrm{ml})$ of water.

\section{DISCUSSION}

In this study, the students habits and their anthropometric measurements were studied. The average BMI of all adolescents was $21.1 \pm 3.25$ and no significant difference was found between genders. In one study, the relationship between obesity and eating disorders was examined and it was reported that the children who were diagnosed with obesity have higher prevalence of eating disorders in their adulthood (22). When the height and weight were examined, it was found that the height and weight of the males were higher than the females. In a study which was about the prevalence of obesity/overweight in students, the rate of obesity in males was found to be higher than females, while the height, weight and BMI measurements of males were similarly higher than females (23). In another study from Turkey, $75.50 \%$ of students had normal body mass index percentages, while were $13.80 \%$ overweight and $7.34 \%$ obese and it had similar results to our study (24). According to the results of our study, males had significantly higher BMI percentile/weight to age percentiles than females.

In the study conducted by Aksoydan and Çakır (2011), they found that the frequency of eating from the school cafeteria decreased and fast food consumption increased according to the level of education (25). The level of Education was not 
evaluated in our study. However, there was no significant difference between the food frequency and age.

One of the results is an insufficient consumption in adolescents of energy and vitamins. In a study, deficiencies were observed in adolescents in terms of energy and some vitamins. In this sense, studies are similar. In our study, students' consumption of ready meals is usually between 2-4 times a week and the students of the shopping from the canteen are mostly packaged foods. In the same study, it was found that packaged food consumption and fast food consumption were high and similar to our study (26).

There was a significant difference between the BMI and the obese family member presence. Similarly, in different studies, obese children were found to have an obese family member (27-29). Another study found that mothers of obese children had higher obesity rates than mothers than non-obese children (30). Studies have reported that, if one family member (a parent) is obese it triples the likelihood of their child being obese. If both parents are obese, it increases the risk by 15 times (31). In another study related to obesity in adolescents, similarly, $20.8 \%$ of adolescents with obese family members were found to be overweight and $6.9 \%$ of them were obese (32). There was no significant difference between skipping meals and BMI, similarly, a there was not a significant difference between obesity and skipping meals.

As a result of this research, it is a positive result that the majority of the students (71.1\%) in adolescence are within the BMI for age percentile in the normal range. However, increasing this ratio; The risk of obesity and the rate of obese individuals would be reduced. As a matter of fact, the rate of overweight and obese students are $17.1 \%$ and it is still high. An evaluation between gender and BMI; found that the number of overweight males was higher than females, making a significant difference $(p<0.05)$. As a matter of fact, the intake of nutrients such as protein, cholesterol, thiamine, riboflavin, sodium, calcium, magnesium, phosphorus, zinc among macro and micronutrients is higher in males. Another important result in the study is the negative correlation between main meal consumption and BMI. The BMI value significantly decreases in a negative way, starting from who consume 2 main meals or less, towards 3 main meals. Students' main meal consumption average is 2.65 meals per day. This situation has shown that regular consumption of 3 main meals is associated with a decrease in BMI. While evaluating the frequency of food consumption in the study, it was observed that carbohydrate consumption percentage had a negative correlation with weight and BMI. This situation once again reveals that increasing the consumption of quality carbohydrates and reducing fat consumption in the adolescent period is important for healthy nutrition.

It was observed that BMI was also significantly higher in adolescents who had an overweight family member. This situation can be interpreted as a result of a genetic predisposition and the way they are raised according to unhealthy nutrition rules.
The acquisition of healthy living habits in students can only be achieved through the education given to the child by parents, teachers and the environment in childhood. Providing basic courses on nutrition in schools, making use of theater, film, animation, story-like role play methods to facilitate this education and ensure its permanence, organizing informative seminars in order to keep teachers always fresh in terms of knowledge, and providing education to families in schools at the same time. Family education should emphasise that it is necessary to sit at a table for dinner as a family and create an environment free from distractions such as television while eating. It should be one of the main aims of education to talk about the big differences that will happen in the lives of their children. These kind of positive behaviours will affect the children's eating habits. Spending time with the family is very important for the psychological development of the children. A child who has breakfast at the table with his/her family in the mornings will not skip the breakfast meal. It will also prevents skipping breakfast with unhealthy snacks from the school canteen. In addition, management and control of unhealthy food advertisements that are frequently encountered on TV and on the Internet will be good for children and adolescents who are overly marketing sensitive. The United Kingdom government has newly announced that they are going to ban all online junk food advertising to tackle obesity.

As recommendations; Nutrition education should be given to students and families in institutions as early as possible. If possible, it should be done that constant dietitian employment is ensured in educational institutions. With this the assessment of nutritional status of students will be monitored by the dietitian and the other health care workers. Growth and development can also be me monitored periodically. The dietician should take part in the supervision of food and menu planning in schools with canteens and cafeterias as a manager. Studies can be planned to make programs that increase physical activity popularity among young people. It should be ensured that courses with healthy nutrition content are added to the curriculum and taught by a dietician in educational institutions.

Ethics Committee Approval: This study was approved by the ethics committee of Istanbul Okan University with the meeting numbered 110 dated 12.06.2019 and number 3 .

Informed Consent: Written consent was obtained from the participants.

Peer Review: Externally peer-reviewed.

Author Contributions: Conception/Design of Study- B.Y., A.Ş.; Data Acquisition- A.Ş., B.Y.; Data Analysis/Interpretation- A.Ş., B.Y.; Drafting Manuscript- A.Ş., B.Y.; Critical Revision of Manuscript- B.Y., A.Ş.; Final Approval and Accountability- B.Y., A.Ş.

Conflict of Interest: Authors declared no conflict of interest.

Financial Disclosure: Authors declared no financial support. 
Etik Komite Onayı: Bu çalışma İstanbul Okan Üniversitesi etik kurulu tarafindan 12.06.2019 tarihli 110. toplantida 3 sayılı karar ile onaylanmıştır.

Bilgilendirilmiş Onam: Katlımcılardan bilgilendirilmiş onam alınmıştır.

Hakem Değerlendirmesi: Dış bağımsız.

Yazar Katkıları: Çalışma Konsepti/Tasarım- B.Y., A.Ş.; Veri Toplama- A.Ş., B.Y.; Veri Analizi/Yorumlama- A.Ş., B.Y.; Yazı Taslağı- A.Ş., B.Y.; İ̧eriğin Eleştirel İncelemesi- B.Y., A.Ş.; Son Onay ve Sorumluluk- B.Y., A.Ş.

Çıkar Çatışması: Yazarlar çıkar çatışması beyan etmemişlerdir.

Finansal Destek: Yazarlar finansal destek beyan etmemişlerdir.

\section{REFERENCES}

1. Das JK, Salam RA, Thornburg KL, Prentice AM, Campisi S, Lassi ZS, Koletzko B, Bhutta ZA. Nutrition in adolescents: physiology, metabolism, and nutritional needs. Ann N Y Acad Sci 2017;1393(1):21-33. https://doi.org/10.1111/nyas.13330

2. Normand E, Franco A, Marcil V. Nutrition and physical activity level of adolescents with idiopathic scoliosis: a narrative review. The Spine Journal 2020; 20(5):785-99. https://doi.org/10.1016/j. spinee.2019.11.012

3. Ozcebe $\mathrm{H}$, Approach to Adolescent Problems in Primary Care. Sted 2002;11:10.

4. Sivagurunathan C, Umadevi R, Rama R, Gopalakrishnan S. Adolescent health: present status and its related programmes in India. Are we in the right direction? J Clin Diagn Res 2015;9(3):LE016. https://doi.org/10.7860/JCDR/2015/11199.5649

5. Lassi ZS, Salam RA, Das JK, Wazny K, Bhutta ZA. An unfinished agenda on adolescent health: Opportunities for interventions. Semin Perinatol 2015;39(5):353-60. https://doi.org/10.1053/j. semperi.2015.06.005

6. Akman M, Tuzun S, Unalan P. Healthy eating patterns and physical activity status of adolescents. Nobel Medicus 2012;22:(8):24-9.

7. Baltacı G, Ersoy G, Karaağaoğlu N, Derman O, Kanbur N. Healthy nutrition and active life in adolescents. Ministry of Health Publication, 2008.

8. Briefel RR, Wilson A, Gleason PM. Consumption of low-nutrient, energy-dense foods and beverages at school, home, and other locations among school lunch partipants and nonpartipants. J Am Diet Assoc 2009;109:79-90. https://doi.org/10.1016/j.jada.2008.10.064

9. Ergul S, Kalkım A. A Major Chronic Disease: Obesity in Childhood and Adolescence. TAF Preventive Medicine Bulletin 2011:10(2):223-30.

10. ErkanT. "Ergenlerde Beslenme”, Türk Ped Arş 2011;46:49-53.

11. Aljaraedah TY, Takruri HR, Tayyem RF. Dietary practices and nutrient intake among adolescents: A general review. Obes Med 2019;16:100145. https://doi.org/10.1016/j.obmed.2019.100145

12. Coley RL, Leventhal $T$, Lynch $A D$, Kull M. Relations between housing characteristics and the well-being of low-income children and adolescents. Dev Psychol 2013;49(9):1775-89. http://doi. org/10.1037/a0031033

13. Gulson B, Mizon K, Taylor A, Wu M. Dietary zinc, calcium and nickel are associated with lower childhood blood lead levels. Environ Res 2019;168:439-444. http://doi.org/10.1016/j.envres.2018.10.029
14. Caka S, Cinar N, Altinkaynak S. Eating disorders in adolescence. Gümüşhane University Journal Of Health Sciences 2018;7:203-209

15. Sucakli M, Celik M, The Etiology and Epidemiology of Obesity. Turkiye Klinikleri J Fam Med 2015;6:1-6.

16. WHO, 2008 https://www.who.int/whosis/whostat/2008/en/Erişim Tarihi: 14.02.2020.

17. Koksal G, Ozel H, Obesity in childhood and adolescence. Ankara, 2012.

18. Kayar H, Utku S, Disease of our time: obesity and its treatment. Mersin Üniversitesi Sağlık Bilim Derg 2013;6(2).

19. Hernández-Cordero $S$, Cuevas-Nasu L, Morán-Ruán MC, MéndezGómez Humarán I, Ávila-Arcos MA, Rivera-Dommarco JA. Overweight and obesity in Mexican children and adolescents during the last 25 years. Nutr Diabetes 2017;13;7(3):e247. http:// doi.org/10.1038/nutd.2016.52

20. Society of Endocrinology and Metabolism of Turkey, 2018. Obesity Diagnosis and Treatment Guide. Available at: http://www.temd. org.tr/admin/uploads/tbl_gruplar/20180525144116-2018-0525tbl_gruplar144108.pdf Accessed at: May 2020

21. WHO-2006, https://www.who.int/childgrowth/standards/ Technical_report.pdf?ua=1 Accesses date: 16.01.2020.

22. TUBER 2015, https://dosyasb.saglik.gov.tr/Eklenti/10915,tuberturkiye-beslenme-rehberipdf.pdf, Accesses date: 13.02.2020.

23. Daştan I Cetinkaya V, Delice ME. The obesity and overweight prevalence among students between the ages of 7 and 18 inizmir. Medical Journal of Bakırköy 2014;10:139-46. http://dio. org/10.5350/BTDMJB201410402

24. Agadayi E, Celik N, Cetinkaya S, Nemmezi Karaca S. Determination of the frequency and the affecting factors of obesity in school age children and adolescents in a rural area in Sivas Province. Ankara Med J 2019;(1):325-36. http://doi.org/10.17098/amj.571393

25. Aksoydan E, Çakır N. Evaluation of nutritional behavior, physical activity level and body mass index of adolescents. Gülhane Med J 2011;53(4):264-70.

26. Meşe Yavuz C, Koca Özer B. Adölesan Dönem Okul Çocuklarında Beslenme Alışkanlıkları ve Beslenme Durumunun Değerlendirilmesi. Journal of Tourism and Gastronomy Studies 2019;7(1):225-43. DOI: 10.21325/jotags.2019.361

27. Serdar Yildirim S, Uskun E. Risk factors affecting obesity development in high school students: A community based casecontrol study. Turk Archives of Pediatrics 2018;53(3):155162. http://doi.org/10.5152/TurkPediatriArs.2018.6566

28. Ulutaş AP, Atla P, Say ZA, Sarı E. Investigation of the Factors Affecting the Formation of 6-18 Years School-Age Children Obesity. Zeynep Kamil Tıp Bülteni 2014;45:192-6.

29. Aykanat Girgin B, Bulantekin Düzalan O. Determining the prevalence of obesity and the effective risk factors in adolescents in the age group of 15-18 years at a secondary school. TJFMPC 2019;13(2):203-11. http://doi.org/10.21763/tjfmpc.454771

30. Onder A, Kavurma C, Celmeli G, Surer Adanır A, Ozatalay E. Assessment of psychopathology, quality of life and parental behaviours of children and adolescents with obesity. İzmir Dr. Behçet Uz Çocuk Hast. Dergisi 2018;8(1):51-58. http://doi. org/10.5222/buchd.2018.051

31. Esen I, Okdemir D. Childhood Obesity: Definition, Etiology and Clinical Evaluation. Firat Med J 2018;23:92-9.

32. Beytül Öge $Y$, Çiçek B, Kaner G. Determining the obesity level and related risk factors in adolescents attending at high schools in Kayseri province. Hygiene and Experimental Biology 2018;75(1):7788. http://doi.org/10.5505/TurkHijyen.2018.33341 